\title{
Thermal niche predicts recent changes in range size for bird species
}

Davide Scridel $^{1,2^{*}}$, Giuseppe Bogliani ${ }^{2}$, Paolo Pedrini ${ }^{1}$, Aaron Iemma ${ }^{1}$, Achaz von Hardenberg $^{3}$, Mattia Brambilla ${ }^{1,4}$

${ }^{1}$ Museo delle Scienze, Sezione Zoologia dei Vertebrati, Corso della Scienza e del Lavoro 3, I38123 Trento, Italy.

${ }^{2}$ Università degli Studi di Pavia, Dipartimento di Scienze della Terra e dell'Ambiente, Via Adolfo Ferrata 9, I-27100, Pavia, Italy.

${ }^{3}$ Conservation Biology Research Group, Department of Biological Sciences, University of Chester, Parkgate Road, CH1 4BJ Chester, UK.

${ }^{4}$ Fondazione Lombardia per l'Ambiente, Settore Biodiversità e Aree protette, Largo 10 luglio 1976 1, I-20822 Seveso, MB, Italy.

*Correspondence author: davide.scride101@universitadipavia.it 


\begin{abstract}
Species distributions are strongly affected by climate, and climate change is largely impacting on species and populations. Thermal niches have been widely used as proxies for estimating thermal sensitivity of species and have been frequently related to community composition, population trends and latitudinal/elevational shifts in distribution. To our knowledge, no work has yet explored the relationship between thermal niche and change in range size (changes in the number of occupied spatial units over time) in bird species. In this paper, we related a 30 years change in range size to Species Thermal Index (STI: average temperature at occurrence sites) and to other factors (i.e. birds' associated habitats, body mass, hunting status) potentially affecting bird populations/range size. We analysed trends of breeding birds range in Italy for a suite of poorly studied cold-adapted animals potentially sensitive to global warming, and a related group of control species taxonomically similar and with comparable mass but mainly occurring at lower/warmer sites. We found a strong positive correlation between change in range size and STI, confirming that recent climatic warming has favoured species of warmer climates and adversely affected species occupying colder areas. A model including STI and birds' associated habitats was only marginally less supported, with forest species performing better than alpine open habitat and agricultural ones. In line with previous works highlighting effects of recent climate change on community composition, species' population trends and on poleward/upward distributional shifts, we found STI to be the most important predictor of change in range size variation in breeding birds.
\end{abstract}

Keywords: change in range size; climate change; cold-dwelling; warm-dwelling; Alps. 


\section{Introduction}

Climate is a major factor determining a species' distribution as this largely depends on species-specific physiological tolerance to temperature (Woodward 1987; Hoffman \& Parson, 1997; Kreyling et al. 2015), precipitation (Tingley et al. 2009; Toledo et al. 2012; Illán et al. 2014) and on climate-driven habitat characteristics (Deutsch et al. 2015). Recent changes in climate have induced range shifts of animal species towards higher latitudes and elevations (Thomas \& Lennon 1999; Parmesan \& Yohe 2003; Zuckerberg et al. 2009; Gillings et al. 2015), altered species' phenology (Roy \& Sparks 2000; Fitter \& Fitter 2002) and affected population dynamics (Thompson \& Ollason 2001; Stephens et al. 2016). Direct and indirect effects of climate change are expected to aggravate the conservation status of many organisms in the current century, with numerous species predicted to become endangered (Parmesan et al. 1999; Thomas et al. 2004; Cahill et al. 2013).

Many studies investigating climate change effects on animal populations have focused on bird species as they are considered good indicators due to their ability to respond rapidly to environmental changes and spatially track suitable climatic conditions (Chen et al. 2011; Maggini et al. 2011). Studies investigating wide-scale effects of climate change on bird populations have commonly used the Species Thermal Index (STI), i.e. the average temperature across a given species' distribution, as a proxy for estimating the thermal sensitivity of a species (e.g. Gaüzère et al. 2015). These kinds of studies typically modelled population trends (changes of population units over time) as a function of climate change (e.g. Jiguet et al. 2010). Other studies evaluated changes in the Community Thermal Index (CTI, i.e. the average temperature for a community of species) over time (e.g. Gaüzère et al. 2015; Tayleur et al. 2016). Generally, those studies reported that population trend varied according to species' STI and that CTI increased coherently with increased temperature (Tingley et al. 2009), displaying consistent latitudinal variation (Devictor et al. 2008). However, to the best 
of our knowledge, until now no study has yet considered the net change in species' range size in a given geographical area over time as a function of the mean temperature experienced by the species across their distributional range. Changes in range size (changes in the number of occupied spatial units over time in a geographical region) related to the climatic sensitivity of the species would signal a very important effect of climate, different than the reported change in population growth (e.g. Jiguet et al. 2010) and community structure (e.g. Gaüzère et al. 2015) in a given area, and even different from a range shift which does not affect range size. This is particularly relevant for cold-dwelling species like mountain birds, which are predicted to be affected by global warming more than warm-dwelling species (Araújo et al. 2011; Pearce-Higgins et al. 2015; Tayleur et al. 2016). Compared to birds in other habitats, mountain birds have been relatively poorly studied, largely due to the logistical problems in surveying in such challenging climatic and topographic environments (Chamberlain et al. 2012; Scridel 2014), but are particularly at risk because of global warming as species are often confined to discrete habitat isolates and can not perform a latitudinal track of suitable climate (Fjeldså et al. 2002; Bech et al. 2009).

Here we investigate the relationship between change in range size and STI for a set of cold dwelling birds and for their closest (non cold-dwelling) relatives breeding in Italy, whilst accounting for other important factors known to potentially affect bird trends such as species broad habitat association (e.g. Chamberlain et al. 2013), hunting status (e.g. Sandercock et al. 2011) and body mass (e.g. Brommer 2008). Moreover, various studies have shown that population trends (Thomas 2008) and extinction risks (Purvis 2008) are not randomly distributed in respect of phylogeny: species that share long evolutionary history are more likely to exhibit similar responses then evolutionary distant ones. Therefore to provide an unbiased assessment of climate change effects we used a phylogenetic comparative approach, which accounts for evolutionary relatedness between species. 


\section{Methods}

\section{Model system}

We worked with the reported change in range size in the last 30 years for breeding bird species in Italy. Italy represents a good study model to investigate the relationship between birds' climatic niche and the variation of their range size trends because i) it encompasses a wide latitudinal and elevational gradient, ii) it comprises different biogeographical regions with different species assemblages (i.e. from Mediterranean islands to high mountains), iii) it includes one third of the Alps, a mountain chain for which strong impacts of climate change have been already observed (Sergio 2003; Maggini et al. 2011; Pernollet et al. 2015) and may act synergically with changes in land use (e.g. Laiolo et al. 2004). Europe has recently experienced a linear increase in average temperatures from the $1980 \mathrm{~s}$ onwards, by over $0.9^{\circ} \mathrm{C}$ (KNMI 2007), but in the Alps the rate of warming has been double the global average (Brunetti et al. 2009) and rising temperatures, higher snow lines and lower snowfalls are predicted to continue (EEA 2010). Adverse effects are therefore expected for these regions hosting many geographically isolated species, often being glacial relicts occurring at the edge of their ecological and climatic niche (e.g. boreo-alpine species and other species found only in high mountains) and often predicted to undergo range contractions and/or population decline as a response to climate change (Maggini et al. 2011; Chamberlain et al. 2013; Viterbi et al. 2013; Braunisch et al. 2014; Brambilla et al. 2015; Pernollet et al. 2015; Brambilla et al. 2016; Brambilla et al. 2017a). To understand whether changes in range size differ according to different STI, we investigated changes in range for breeding bird species by considering a set of species comprising closely related taxa with largely different STI, in order to get an indirect measure of the species' sensitivity to climate change. Firstly, we chose bird species displaying in Italy a breeding distribution strictly related to the main mountains (i.e. Alps and Apennines; Nardelli et al. 2015). We included boreo-alpine species (rock ptarmigan Lagopus 
muta, pygmy owl Glaucidium passerinum, boreal owl Aegolius funereus), species occurring in southern European mountains (alpine accentor Prunella collaris, yellow-billed chough Pyrrhocorax graculus, white-winged snowfinch Montifringilla nivalis) and other species that in southern Europe and in the Alps occur only or predominantly on mountains or in relatively cold areas: hazel grouse Bonasa bonasia, black grouse Lyrurus tetrix, capercaillie Tetrao urogallus, nutcracker Nucifraga caryocatactes, water pipit Anthus spinoletta, citril finch Carduelis citrinella, common redpoll Carduelis flammea, ring ouzel Turdus torquatus, wallcreeper Tichodroma muraria, three-toed woodpecker Picoides tridactylus, black woodpecker Dryocopus martius, grey-headed woodpecker Picus canus, willow tit Parus montanus (although the latter three species occur broadly in lowland habitats in centralnorthern Europe, in the Alps and in southern Europe they are mostly associated with relatively cold areas). Secondly, for each of the above mentioned taxa $(n=19)$, whenever possible a control species was chosen $(n=19)$, taking the one most closely related according to Roquet et al. (2014) and generally associated with lower elevation in order to have a balanced sample (Table 1). With such ad hoc species selection, we ensured a phylogenetically balanced sample of species, the inclusion of cold-dwelling taxa and of other not specialized for cold environments, the focus on species with similar movement strategies (all species apart tree pipit Anthus trivialis being resident or short-distance migrants), the exclusion of species for which change in range size may be due mostly to improved knowledge or reintroduction/restocking projects carried out between the two reference periods (as actually occurred for some species; Nardelli et al. 2015). 
Species Thermal Index and distribution trends

To quantify STI for each species we gathered breeding distribution data available from the EIONET portal (http://www.eionet.europa.eu), which provided presence/absence data at a $10 \mathrm{~km} \times 10 \mathrm{~km}$ resolution for 23 European countries (i.e. UK, France, Italy, Slovenia, Spain, Portugal, Austria, Denmark, Sweden, Finland, Greece, Belgium, Gibraltar, Slovakia, Malta, Lithuania, Latvia, Ireland, Hungary, Germany, Estonia, Romania, Czech). For each species, we merged all available data to create a large-scale breeding distribution map using a geographic information system (GIS) software (QGIS; Quantum GIS Development Team 2016; GRASS; GRASS Development Team 2015). We then coupled the above-mentioned species' digitized breeding distribution with 30 -arc seconds resolution data describing the mean annual temperature (downloaded from Wordclim database version 1.4; http://www.worldclim.org; Hijmans et al. 2005). STI were consequently calculated by averaging mean, median, minimum and maximum temperature $\left(\right.$ in $\left.{ }^{\circ} \mathrm{C}\right)$ experienced by each species during the breeding season across its distribution range. To date, many studies have used a variety of thermal indexes to evaluate potential responses of bird communities to climate change ranging from thermal maximum and minimum (mean of hottest/coldest 5\% cells; e.g. Jiguet et al. 2010), thermal range (difference between thermal maximum \& minimum; e.g. Jiguet et al. 2010), seasonal thermal average (mean temperatures during breeding period; e.g. Devictor et al. 2008), coldest-month mean temperature (e.g. Green et al. 2008), annual temperature sum above $5^{\circ} \mathrm{C}$ (e.g. Green et al. 2008). To minimize collinearity, we used variance inflation factors (VIFs) on our four temperature predictors and highly collinear variables (VIF > 5) were omitted following Zuur et al. (2009). There were high levels of collinearity between these variables and only mean annual temperature was used considered the be the most representative estimate for the thermal niche of the study species, 
due to the largely non-migratory status of our target species (most species are resident, and only tree pipit Anthus trivialis is a long-distance migrant).

To estimate change in range size, we used long-term bird distribution trends from Nardelli et al. (2015), which compared occupied vs unoccupied cells of breeding species in Italy between the 1980s (1983-1986, according to data available for each species) and 2012, therefore calculating a net change of range size (Table 1). Species ranges were estimated by collating all available data, such as regional and local atlases, published reports, papers, monitoring schemes (Nardelli et al. 2015). Given that most of the sources used to define species range were general and not species-specific, the potential effect of confounding factors such as an increase of knowledge should affect in the same way all the species, thus it is unlikely to produce any bias in our analyses. The only partial exception to this pattern is represented by an increased effort at high elevation in the common birds monitoring scheme (MITO 2000 project Pan-European Common Bird Monitoring Scheme). We stress that species' net changes in range size reported in Nardelli et al. (2015) are unlikely biased in respect of elevation as these are in line with various national (Fornasari et al. 2004; Gustin et al. 2010; Rete Rurale Nazionale \& LIPU 2014) and international studies on population trends (i.e. Zbinden et al. 2005), which generally highlight a wide scale decline for mountain birds, particularly marked for open-habitat species.

\section{Statistical analysis}

To tests the hypothesis that STI is associated with changes in range size (and thus that coldadapted species have contracted more their range size than warm-dwelling species), we fitted phylogenetic general least square models (PGLS) implemented in the package "Caper" (Orme 
et al. 2013; ver.0.5.2) in the statistical environment " $R$ " version 3.2.3 (R Core Team 2015). The response variable was the long-term trend (as percentage variation reported in Nardelli et al. 2015) in the national breeding range of the selected bird species. Explanatory variables were the STI of each species and three other factors potentially driving variation: the broad habitats to which the species is mostly associated in Italy (forest [ $\mathrm{n}=16$ species], alpine open $[\mathrm{n}=12]$ and agricultural habitats $[\mathrm{n}=10]$; Cramp et al. 1977 - 1994), a categorical variable defining the prevalent hunting status in Italy (i.e. hunted/non-hunted; Art. 2, Law 157/92) and the average body mass of each species as a proxy for demographic traits (Cramp et al. 1977 1994; Julliard et al. 2003; Brommer et al. 2008). An interaction term between species' associated habitat and STI was also included in order to test the hypothesis that the relationship between STI and changes in range size differs across habitats. PGLS models were chosen in order to incorporate the covariance between related birds and therefore accounting for the non-independence of data points due to common ancestry (Paradis 2014). Firstly, we built a phylogenetic tree for our selected species based on the supertree from Jetz et al. (2012) and trimmed it using the related website www.birdtree.org. A co-variance matrix was then produced calculating the branch lengths of the phylogenetic tree and fitted in the PGLS model to estimate maximum likelihood of the parameter $\lambda$ and for phylogenetic signal in the model residuals (Pagel's $\lambda$ ). A value of $\lambda=0$ represents no phylogenetic signal, whilst $\lambda=1$ means a high phylogenetic signal and therefore consistent with a Brownian motion model of trait evolution (Pagel 1999). Model selection for fixed terms was then performed by comparing Akaike's Information Criterion corrected for small sample size (AICc; Burnham \& Anderson 2002) using the dredge function in the R package 'MuMIn' (Barton 2015), which allows to generate mathematical models (PGLS in our case) using all combinations of variables.

\section{Results}


Our sample of 38 species covered a wide range of thermal positions (mean STI $7.6 \pm 0.4{ }^{\circ} \mathrm{C}$, range $3.1^{\circ} \mathrm{C}$ to $13^{\circ} \mathrm{C}$, uncertainties expressed in SE units), with the 'coldest' species being rock ptarmigan Lagopus muta and the 'warmest' being rock sparrow Petronia petronia. STI values were cooler for species of alpine open habitat (mean $5.6 \pm 0.4{ }^{\circ} \mathrm{C}$ ) than for species of forest (mean $7.1 \pm 0.6{ }^{\circ} \mathrm{C}$ ) and agricultural habitat (mean $10.7 \pm 0.4{ }^{\circ} \mathrm{C}$ ). Changes in range size were negative for alpine open habitat species (mean \% trend: $-4.4 \pm 2.3$ ), positive for agricultural $(12.9 \pm 6.4)$ and, especially, for forest species $(14.2 \pm 5.1)$. Based on AICc, the most supported model explaining change in range size in bird only included STI as a fixed variable (Table 2) and explained a good proportion of the variance (adjusted- $\mathrm{R}^{2}=0.36$ ). All other models with similar support $(\triangle \mathrm{AICc}<2)$ included the most supported as a nested model, thus all the other parameters may be considered uninformative. For the most supported model, Pagel's $\lambda$ was equal to 0.48 .

We thus found a positive correlation between long-term changes in range size of Italian breeding birds and the respective thermal niche (STI) of a species (Fig. 1): species which have experienced losses in their distribution were mostly associated with cold STI values. A poorly supported effect (uninformative parameters) was found for habitat and for the habitat x STI interaction, generally suggesting a more favourable change in range size for forest species than for those dwelling open habitats and, especially, agricultural ones.

\section{Discussion}

This work highlights for the first time the importance of thermal niche (described by means of the average temperature experienced by a species across its breeding range) as a predictor for the change in breeding range size for a suite of European birds with different thermal niches 
and inhabiting different habitats. Our work analysed changes in range size in Italy, which represents an optimal context for such an assessment, given its location at the southern boundary of Europe and the presence of wide latitudinal and elevational gradients.

Thermal niche has been frequently reported as the most important component of the climatic niche of birds and it is known to be a reliable tool to evaluate climate change effects on species dynamics (Jiguet et al. 2007; Barnagaud et al. 2012; Howard et al. 2015; Stephens et al. 2016). Our findings are consistent with previous studies reporting the importance of thermal niche in predicting bird population trends (Jiguet et al. 2010; Thaxter et al. 2010; Pearce-Higgins et al. 2015) and complement them by highlighting the relationship between thermal niche and range dynamics, in addition to the already reported link between thermal niche and population trends.

The overwhelming importance of STI in predicting changes in range size variation for breeding bird species in the last 30 years provides additional support for the strong effect of climate change on the change in the size of their breeding range, even over a relatively short timeframe. Thousands of cases of species changing their distribution in relation to climate change have been already reported (Bellard et al. 2012), mostly in the form of latitudinal and elevational shifts, which seem particularly frequent in species displaying good dispersal abilities (Parmesan 2006). Range contraction have been indeed reported for species of polar and high-mountain regions (Forero-Medina 2010). Consistently, our results further confirmed how cold-adapted species inhabiting mountain regions are at particular high risk, as their range has already contracted most likely because of climate change effects. Indeed it is likely easier for lowland species to track suitable climates by performing latitudinal shifts, whereas for mountain species, confined to discrete habitat isolates, tracking suitable climates almost invariably means contracting the relative range (Fjeldså et al. 2002; Bech et al. 2009). In fact, 
also species showing no or positive changes in range size might have shifted their range, but only in the case of cold-adapted species range shifts resulted in definite range contraction. The positive correlation between changes in range size bird distribution trends and STI supported our initial expectation, suggesting that recent climatic warming has favoured species adapted to warm areas while adversely impacting on species occupying cool sites. Tayleur et al. (2016) found that changes in Community Thermal Indexes were driven by warm-dwelling species colonising new sites, whereas cold-dwelling species contracted. Pearce-Higgins et al. (2015) found that cold-adapted species experienced more negative effects of higher temperatures than species associated with warmer temperatures. In addition to thermal niche, a minor effect of habitat (an 'uninformative parameter' according to Arnold 2010) partly emerged from models, basically highlighting a positive change in size for forest species (as shown by position of e.g. woodpecker species in Fig. 1), coherent with the better conservation status shown by woodland birds at the national level, determined by an increase in both woodland cover and quality (see Brambilla et al. 2013 and references therein). The only cold-dwelling species showing a positive change in range size is three-toed woodpecker, and in general woodpeckers, tits and other typical forest-dwelling species showed positive variation of range size. Some forest species experienced more positive variation in range size than some farmland species with a higher STI (Fig. 1). However, consistent with the prominent effect of STI, even the forest species with the lowest STI values, such as boreal and pygmy owl, have experienced negative changes in their breeding distribution: these are species showing a cold STI $\left(4.9 \mathrm{C}^{\circ}\right.$ and $5.1 \mathrm{C}^{\circ}$ respectively $)$ and they might be particularly sensitive to climate warming. This interpretation is in line with other studies, which predicted boreal and pygmy owl distribution to further contract according to future global warming scenarios (Brambilla et al. 2015, Brambilla et al. 2017a). In contrast, the respective control species in the same habitat (i.e. tawny owl Strix aluco) has experienced 
a positive trend in the last 30 years whilst having a higher STI $\left(9.6 \mathrm{C}^{\circ}\right)$. Tawny owl distribution is known to be limited by climate (Vrezec \& Tome 2004) and recent increases in distribution and breeding success in Finnish populations have been attributed to climate warming (Mikkola 1983; Solonen 2005).

Except for tree pipit, all other alpine open habitat species were associated with long-term losses in range and low STI. For some of those species (e.g. ptarmigan) strong contractions have also been observed in other Alpine regions (Revermann et al. 2012; Pernollet et al. 2015), with global warming effects likely to influence not just the habitat but also the breeding mechanisms of species (Martin \& Weibe 2004). Furthermore, our results agree also with other studies, which have forecasted future losses in distribution of open habitat species (i.e. water pipit) due to climate and to the disappearance of alpine grassland as it becomes slowly colonised by shrub and trees (Chamberlain et al. 2013). Even if we cannot rule out the potential impact of land use change, and in particular of land abandonment (see e.g. Brambilla et al. 2010, 2017b), modelling results suggested an overwhelming importance of STI and thus a major impact of climate change.

In conclusion, our work provided evidence for a direct link between species' thermal niche and the change in range size in the last 30 years. Coherently with previous works highlighting an effect of recent climate change on community composition, species' population trend, and on poleward or upward distributional shift, we found climate warming to be the most likely factor in explaining the change in range for breeding birds in Italy.

\section{Acknowledgments}

We are grateful to S. Tenan, M. Morganti, R. Ambrosini for useful discussions and to three anonymous reviewers for helpful comments. The study was partially funded by the Autonomous Province of Trento and by the Paneveggio-Pale di San Martino Natural Park. 


\section{References}

Araújo MB, Alagador D, Cabeza M, Nogués-Bravo D, Thuiller W (2011) Climate change threatens European conservation areas. Ecol Lett 14: 484-492.

Arnold TW (2010) Uninformative parameters and model selection using Akaike's information criterion. J Wildl Manage 74: 1175-1178.

Barnagaud JY, Devictor V, Jiguet F, Barbet-Massin M, Le Viol I, Archaux F (2012) Relating Habitat and Climatic Niches in Birds. PLoS Biol 7: e32819.

Barton K (2015) MuMIn: Multi-Model Inference. R package version 1.15.1. URL: http://CRAN.R-project.org/ package=MuMIn.

Bech, N, Boissier, J, Drovetski, S, Novoa, C (2009) Population genetic structure of rock ptarmigan in the 'sky islands' of French Pyrenees: implications for conservation. Anim Conserv 12: 138-146.

Bellard C, Bertelsmeier C, Leadley P, Thuiller W, Courchamp F (2012) Impacts of climate change on the future of biodiversity. Ecol Lett 15: 365-377.

Brambilla M, Casale, F, Bergero, V, Bogliani, G, Crovetto, GM, Falco, R, Roati, M, Negri, I (2010) Glorious past, uncertain present, bad future? Assessing effects of land-use changes on habitat suitability for a threatened farmland bird species. Biol Cons 143: 2770-2778. 
Brambilla M, Gustin M, Celada C (2013) Species appeal predicts conservation status. Biol Cons 160: 209-213.

Brambilla M, Bergero V, Bassi E, Falco R (2015) Current and future effectiveness of Natura 2000 network in the central Alps for the conservation of mountain forest owl species in a warming climate. Eur J Wildlife Res 61: 35-44.

Brambilla M, Pedrini P, Rolando A, Chamberlain DE (2016) Climate change will increase the potential conflict between skiing and high-elevation bird species in the Alps. J Biogeogr 43: 2299-2309.

Brambilla M, Caprio E, Assandri G, Scridel, D, Bassi, E, Bionda, R, Celada, C, Falco, R, Bogliani, G, Pedrini, P, Rolando, A, Chamberlain, D (2017a) A spatially explicit definition of conservation priorities according to population resistance and resilience, species importance and level of threat in a changing climate. Diversity Distrib 00:1-

12. https://doi.org/10.1111/ddi.12572

Brambilla M, Gustin, M, Vitulano, S, Falco, R, Bergero, V, Negri, I, Bogliani, G, Celada, C (2017b) Sixty years of habitat decline: impact of land-cover changes in northern Italy on the decreasing ortolan bunting Emberiza hortulana. Reg Environ Change 17: 323-333.

Braunisch V, Coppes J, Arlettaz R, Suchant R, Zellweger F, Bollmann K (2014) Temperate Mountain Forest Biodiversity under Climate Change: Compensating Negative Effects by Increasing Structural Complexity. PLoS Biol 9: e97718. 
Brommer JE (2008) Extent of recent polewards range margin shifts in Finnish birds depends on their body mass and feeding ecology. Ornis Fenn 85: 109-117.

Brunetti M, Lentini G, Maugeri M, Nanni T, Auer I, Böhm R, Schöener W (2009) Climate variability and change in the Greater Alpine Region over the last two centuries based on multi-variable analysis. Int J Climatol 29: 2197-2225.

Burnham KP, Anderson DR (2002) Model Selection and Multimodel Inference: A Practical Information-Theoretic Approach ( $2^{\text {nd }}$ edition). Springer-Verlag.

Cahill AE, Aiello-Lammens ME, Fisher-Reid MC, Hua X, Karanewsky CJ, Yeong Ryu H, Sbeglia GC, Spagnolo F, Waldron JB, Warsi O, Wiens JJ (2013) How does climate change cause extinction? Proc R Soc Lond [Biol] 280: 21231890.

Chamberlain DE, Arlettaz R, Caprio E, Maggini R, Pedrini P, Rolando A, Zbinden N (2012) The altitudinal frontier in avian climate impact research. Ibis 154: 205-209.

Chamberlain DE, Negro M, Caprio E, Rolando A (2013) Assessing the sensitivity of alpine birds to potential future changes in habitat and climate to inform management strategies. Biol Cons 167: 127-135.

Chen IC, Hill JK, Ohlemüller R, Roy DB, Thomas CD (2011) Rapid Range Shifts of Species Associated with High Levels of Climate Warming. Science 333: 1024-1026. 
Cramp S, Simmons KEL, Perrins CM (1977 - 1994) Handbook of the birds of the Europe, the Middle East and North America: birds of the Western Palearctic. Vol. 1 - 9. - Oxford Univ. Press.

Deutsch C, Ferrel A, Seibel B, Portner HO, Huey RB (2015) Climate change tightens a metabolic constraint on marine habitats. Science 348: 1132.

Devictor V, Julliard R, Jiguet F, Couvet D (2008) Birds are tracking climate warming, but not fast enough. Proc R Soc Lond [Biol] 275: 2743-2748.

EEA (2010) Europe's Ecological Backbone: Recognising the True Value of our Mountains. EEA Report 6/2010. Copenhagen: European Environment Agency.

Fitter AH, Fitter RSR (2002) Rapid changes in flowering time in British plants. Science 296: $1689-1691$.

Fjeldså, J, Bowie, RCK, Rahbek, C (2012) The role of mountain ranges in the diversification of birds. Annu Rev Ecol Evol Syst 43: 249-265.

Forero-Medina G, Joppa L, Pimm SL (2011) Constraints to Species’ Elevational Range Shifts as Climate Changes. Cons Biol 25: 163-171.

Gaüzère P, Jiguet F, Devictor V (2015) Rapid adjustment of bird community compositions to local climatic variations and its functional consequences. Glob Change Biol 21: 3367-3378. 
Gillings S, Balmer DE, Fuller RJ (2015) Directionality of recent bird distribution shifts and climate change in Great Britain. Glob Change Biol 21: 2155-2168.

GRASS Development Team (2015) Geographic Resources Analysis Support System (GRASS) Software, Version 7.0. Open Source Geospatial Foundation. http://grass.osgeo.org.

Green RE, Collingham YC, Willis SG, Gregory RD, Smith KW, Huntley B (2008) Performance of climate envelope models in retrodicting recent changes in bird population size from observed climatic change. Biol Lett 4: 599-602.

Hijmans RJ, Cameron SE, Parra JL, Jones PG, Jarvis A (2005) Very high resolution interpolated climate surfaces for global land areas. Int J Climatol 25: 1965-1978.

Hoffman AA, Parsons PA (1997) Extreme Environmental Change and Evolution. Cambridge University Press, Cambridge.

Howard C, Stephens PA, Pearce-Higgins JW, Gregory RD, Willis SG (2014) Improving species distribution models: the value of data on abundance. Methods Ecol Evol 5: 506-513.

Illán JG, Thomas, CD, Jones JA, Wong WK, Shirley SM, Betts MG (2014) Precipitation and winter temperature predict long-term range-scale abundance changes in Western North American birds. Glob Change Biol 20: 3351-3364.

Jetz W, Thomas GH, Joy JB, Hartmann K, Mooers AO (2012) The global diversity of birds in space and time. Nature 491: 444-448. 
Jiguet F, Gadot A, Julliard R, Newson S, Couvet D (2007) Climate envelope, life history traits and the resilience of birds facing global change. Glob Change Biol 13: 1673-1685.

Jiguet F, Devictor V, Ottvall R, Van Turnhout C, Van der Jeugd H, Lindström Å (2010) Bird population trends are linearly affected by climate change along species thermal ranges. Proc $\mathrm{R}$ Soc Lond [Biol] 277: 3601-3608.

Julliard R, Jiguet F, Couvet D (2003) Common birds facing global changes: what makes a species at risk? Glob Change Biol 10: 148-154.

KNMI (2007) Climate Research Unit (CRU) (http://climexp.knmi.nl). Gridded temperature data are available at http:// www.cru.uea.ac.uk/cru/data/temperat.htm.

Kreyling J, Schmid S, Aas G (2015) Cold tolerance of tree species is related to the climate of their native ranges. J Biogeogr 42: 156-166.

Laiolo P, Dondero F, Ciliento E, Rolando A (2004) Consequences of pastoral abandonment for the structure and diversity of the alpine avifauna. J Appl Ecol 41:294-304.

Maggini R, Lehmann A, Kéry M, Schmid H, Beniston M, Jenni L, Zbinden N (2011) Are Swiss birds tracking climate change? Detecting elevational shifts using response curve shapes. Ecol Model 222: 21-32. 
Martin K, Wiebe KL (2004) Coping mechanisms of alpine and arctic breeding birds: extreme weather and limitations to reproductive resilience. Integr Comp Biol 44: 177-185.

Mikkola H (1983) Owls of Europe. T. \& A. D. Poyser, Calton.

Nardelli R, Andreotti A, Bianchi E, Brambilla M, Brecciaroli B, Celada C, Dupré E, Gustin, M, Longoni V, Pirrello S, Spina F, Volponi S, Serra, L (2015) Rapporto sull'applicazione della Direttiva 147/2009/CE in Italia: dimensione, distribuzione e trend delle popolazioni di uccelli (2008-2012). ISPRA, Serie Rapporti, 219/2015.

Orme D, Freckleton R, Thomas G, Petzoldt T, Fritz S, Isaac N, Pearse W (2013) caper: Comparative Analyses of Phylogenetics and Evolution in R. R package version 0.5.2. https://CRAN.R-project.org/package=caper.

Pagel M (1999) Inferring the historical patterns of biological evolution. Nature 401: 877-884.

Paradis E (2014) An Introduction to the Phylogenetic Comparative Method. In Modern Phylogenetic Comparative Methods and Their Application in Evolutionary Biology (pp. 318). Springer Berlin Heidelberg.

Parmesan C, Ryrholm N, Stefanescu C, Hill JK, Thomas CD, Descimon H, Huntley B, Kaila, L, Kullberg J, Tammaru T, Tennent WJ, Thomas JA, Warren M (1999) Poleward shifts in geographical ranges of butterfly species associated with regional warming. Nature 399: 579583. 
Parmesan C, Yohe G (2003) A globally coherent fingerprint of climate change impacts across natural systems. Nature 421: 37-42.

Parmesan C (2006) Ecological and evolutionary responses to recent climate change. Annu Rev Ecol Evol Syst 37: 637-69.

Pearce-Higgins JW, Eglington SM, Martay B, Chamberlain DE (2015) Drivers of climate change impacts on bird communities. J Anim Ecol 84: 943-954.

Pernollet CA, Korner-Nievergelt F, Jenni L (2015) Regional changes in the elevational distribution of the Alpine Rock Ptarmigan Lagopus muta helvetica in Switzerland. Ibis 157: $823-836$.

Purvis A (2008) Phylogenetic approaches to the study of extinction. Annu Rev Ecol Evol Syst 39: $301-319$.

Quantum GIS Development Team (2016) Quantum GIS Geographic Information System. Open Source Geospatial Foundation Project. http://qgis.osgeo.org.

R Core Team (2015) R: A language and environment for statistical computing. R Foundation for Statistical Computing, Vienna, Austria.URL https://www.R-project.org/.

Revermann R, Schmid H, Zbinden N, Spaar R, Schröder B (2012) Habitat at the mountain tops: how long can Rock Ptarmigan (Lagopus muta helvetica) survive rapid climate change in the Swiss Alps? A multi-scale approach. J Ornithol 153: 891-905. 
Roquet C, Lavergne S, Thuiller W (2014) One tree to link them all: a phylogenetic dataset for the European Tetrapoda. PLOS Currents - Tree of Life.

Roy DB, Sparks TH (2000) Phenology of British butterflies and climate change. Glob Change Biol 6: 407-416.

Sandercock BK, Nilsen EB, Brøseth H, Pedersen, HC (2011) Is hunting mortality additive or compensatory to natural mortality? Effects of experimental harvest on the survival and causespecific mortality of willow ptarmigan. J Anim Ecol 80: 244-258.

Sanderson FJ, Pople RG, Ieronymidou C, Burfield IJ, Gregory RD, Willis SG, Howard C, Stephens PA, Beresford AE, Donald PF (2015) Assessing the performance of EU nature legislation in protecting target bird species in an era of climate change. Conserv Lett 9: 172180.

Sergio F (2003) Relationship between laying dates of black kites Milvus migrans and spring temperatures in Italy: rapid response to climate change? J Avian Biol 34: 144-149.

Scridel D (2014) Ecology and conservation of birds in upland and alpine habitats: a report on the BOU's Annual Conference held at the University of Leicester, 1-3 April 2014. Ibis 156: 896-900.

Solonen T (2005) Breeding of the tawny owl Strix aluco in Finland: responses of a southern colonist to the highly variable environment of the north. Ornis Fenn 82: 97-106. 
Stephens PA, Mason LR, Green RE, Gregory RD, Sauer JR, Alison J, Aunins A, Brotons L, Butchart SHM, Campedelli T, Chodkiewicz T, Chylarecki P, Crowe O, Elts J, Escandell V, Foppen RPB, Heldbjerg H, Herrando S, Husby M, Jiguet F, Lehikoinen A, Lindström A, Noble DG, Paquet JY, Reif J, Sattler T, Szép T, Teufelbauer N, Trautmann S, van Strien, AJ, van Turnhout CAM, Vorisek P, Willis SG (2016) Consistent response of bird populations to climate change on two continents. Science 352: 84.

Tayleur CM, Devictor V, Gaüzère P, Jonzén N, Smith HG, Lindström Å (2016) Regional variation in climate change winners and losers highlights the rapid loss of cold-dwelling species. Divers Distrib 22: 468-480.

Thaxter CB, Joys A, Gregory R, Baillie SR, Noble DN (2010) Hypotheses to explain patterns of population change among breeding bird species in England. Biol Cons 143: 2006-2019.

Thomas CD, Lennon JJ (1999) Birds extend their ranges northwards. Nature 399:213.

Thomas CD, Cameron A, Green RE, Bakkenes B, Beaumont LJ, Collingham YC, Erasmus, BFN, Ferriera De Siqueira M, Grainger A, Hannah L, Hughes L, Huntley B, Van Jaarsveld AS, Midgley GF, Miles L, Ortega-Huerta MA, Peterson AT, Phillips OL, Williams SE (2004) Extinction risk from climate change. Nature 427: 145-148.

Thomas GH (2008) Phylogenetic distributions of British birds of conservation concern. Proc Roy Soc [Biol] 275: 2077-2083. 
Thompson PM, Ollason JC (2001) Lagged effects of ocean climate change on fulmar population dynamics. Nature 413: 417-420.

Tingley MW, Monahan WB, Beissinger SR, Moritz C (2009) Birds track their Grinnellian niche through a century of climate change. PNAS 106: 19637-19643.

Toledo M, Peña-Claros M, Bongers F, Alarcón A, Balcázar J, Chubiña J, Leaño C, Licona JC, Poorter L (2012) Distribution patterns of tropical woody species in response to climatic and edaphic gradients. J Ecol 100: 253-263.

Viterbi R, Cerrato C, Bassano B, Bionda R, von Hardenberg A, Provenzale A, Bogliani G (2013) Patterns of biodiversity in the northwestern Italian Alps: a multi-taxa approach. Community Ecol, 14: 18-30.

Vrezec A, Tome D (2004) Altitudinal segregation between Ural Owl Strix uralensis and Tawny Owl S. aluco: evidence for competitive exclusion in raptorial birds. Bird Study 51: 264-269.

Woodward FI (1987) Climate and Plant Distribution. Cambridge University Press, Cambridge, 1987.

Zuckerberg B, Woods AM, Porter WF (2009) Poleward shifts in breeding bird distributions in New York State. Glob Change Biol 15: 1866-1. 
Zuur, AF, Ieno, EN, Walker, NJ, Saveliev, AA, Smith, GM (2009) Mixed Effects Models and Extensions in Ecology with R. Springer, New York. 